\title{
Wild pig (Sus scrofa L.) occupancy patterns in the Brazilian Atlantic forest
}

\author{
Carla Grasiele Zanin Hegel ${ }^{1 *}$, Luane Reis dos Santos ${ }^{2}$, Mauro Pichorim $^{3}$ \& Miguel Ângelo Marini ${ }^{2}$ \\ ${ }^{1}$ Universidade Regional Integrada do Alto Uruguai e das Missões, Departamento de Ciências Biológicas, \\ Erechim, RS, Brasil \\ ${ }^{2}$ Universidade de Brasília, Departamento de Zoologia, Brasília, DF, Brasil \\ ${ }^{3}$ Universidade Federal do Rio Grande do Norte, Departamento de Botânica e Zoologia, Natal, RN, Brasil \\ *Corresponding author: Carla Grasiele Zanin Hegel, e-mail: carlinhahehe@yahoo.com.br
}

HEGEL C.G.Z., SANTOS L.R., PICHORIM M., MARINI M.Â. Wild pig (Sus scrofa L.) occupancy patterns in the Brazilian Atlantic forest. Biota Neotropica. 19(4): e20180719. http://dx.doi.org/10.1590/1676-0611BN-2018-0719

\begin{abstract}
Despite the great impacts of invasive wild pig (Sus scrofa) to natural ecosystems, habitat use by this species in the neotropics remains poorly studied. Here, we investigated the effects of local habitat and landscape covariates (vegetation types, running watercourses and roads) on occupancy patterns of wild pig in the Atlantic Forest of southern Brazil. We used single season occupancy modeling to estimate detection $(p)$ and occupancy $(\psi)$ probabilities, using 8-day camera-trap monitoring of 100 sampled sites. The cameras detected wild pig in 64 sites (naïve occupancy $=64 \%$ ). The four best models explained $72.7 \%$ of the occupancy patterns, and the top model (with "water" variable) had a weight of $28.5 \%$. Even though none of the tested variables had high explanatory power of wild pig occupancy, the water variable had a negative effect trend $(\beta=-1.124 ; \mathrm{SE}=0.734)$, with $59 \%$ of occupancy when water was present and $82 \%$ when it was absent around the sampling sites. Vestiges of the presence of wild pig in different vegetation types revealed that they used plantations of Pinus sp., native forests, and corn and oat crops. The occupation pattern shows that wild pig are generalist at our study site at the Atlantic Forest being found everywhere, raising ecological and economic concerns about the high potential negative effects of its invasion.
\end{abstract}

Keywords: Occupancy modeling, feral pig, wild boar, landscape, Neotropics.

\section{Padrões de ocupação do javali (Sus scrofa L.) na Mata Atlântica brasileira}

Resumo: Apesar dos grandes impactos da invasão do javali (Sus scrofa) nos ecossistemas naturais, o uso de hábitats por esta espécie nos neotrópicos ainda permanece pouco estudado. Aqui, nós investigamos os efeitos do hábitat local e de covariáveis da paisagem (tipos de vegetação, cursos d'água e estradas) sobre os padrões de ocupação do javali na Mata Atlântica do sul do Brasil. Utilizamos a modelagem de ocupação de estação única para estimar as probabilidades de detecção (p) e de ocupação $(\psi)$ dos javalis, usando monitoramento de armadilha fotográfica por 8 dias em 100 locais. As câmeras detectaram javalis em 64 locais (ocupação ingênua =64\%). Os quatro melhores modelos explicaram $72,7 \%$ dos padrões de ocupação, e o melhor modelo (com variável "água") teve um peso de $28,5 \%$. Embora nenhuma das variáveis testadas apresentaram alto poder explicativo na ocupação do javali, a variável água foi a que contribuiu com uma tendência de efeito negativo $(\beta=-1,124$; SE $=0,734)$, com 59\% de ocupação quando a água estava presente e $82 \%$ quando estava ausente nos pontos de amostragem. Vestígios da presença de javali em diferentes tipos de vegetação revelaram que eles utilizaram plantações de Pinus sp., florestas nativas e culturas de milho e aveia. O padrão de ocupação mostra que o javali é extremamente generalista em nosso local de estudo na Mata Atlântica, sendo encontrado em todos os lugares, o que levanta preocupações ecológicas e econômicas sobre os potenciais efeitos negativos de sua invasão.

Palavras-chave: Modelagem de ocupação, porcos asselvajados, javalis, paisagem, Neotrópicos. 


\section{Introduction}

Non-native and invasive species are found in almost all ecosystems worldwide, a number that has increased markedly in the last two decades (Blackburn et al. 2011). These accidentally or intentionally introduced species are causing several damages to native species (Vitule et al. 2012), changes in community structure and in dynamics of natural ecosystems (Martin et al. 2009) and even reduction in biological diversity (Chapin III et al. 2000). Furthermore, anthropogenic disturbances of natural environments favor the success of invasive species (Gurevitch \& Padilla 2004), and many changes promoted by invasive species are gradual and unnoticed (Simberloff et al. 2013).

Wild pig (Sus scrofa L.) are those pig invasive/non-native/ introduced (Keiter et al. 2016, Melletti \& Meijaard 2017), currently considered one of the 100 most invasive species of the world (Lowe et al. 2000, IUCN 2019). After humans, wild pig comprises the largebodied size mammal with the broadest distribution in the world (Massei \& Genov 2004; Barrios-García \& Ballari 2012). Since the wild pig had a wide native geographical distribution, it can be considered pre-adapted to a large array of environmental conditions (Baskin \& Danell 2003). Wild pig can move long distances in one single day in search for food (Leaper et al. 1999) and are able to cause major impacts on native plants and animals, on crop plantations and domestic animals, and on ecological processes (Oliver \& Brisbin 1993; Hadjisterkotis 2004; Massei \& Genov 2004; Barrios-García \& Ballari 2012; Myrphy et al. 2014). However, resource abundance and distribution can have strong impacts on population dynamics and survival rates of wild pig (Ostfeld $\&$ Keesing 2000). Wild pig population growth and abundance can be determined by presence or absence of food resources (Jedrzejewska et al. 1997; Honda 2009), landscape structure (Acevedo et al. 2006) and climatic factors (Honda 2009).

Models have been used recently to predict the distribution of wild pig and to understand their occupancy patterns in native and non-native areas (Bosch et al. 2012, Bosch et al. 2014, Acevedo et al. 2014, Gantchoff \& Belant 2015, McClure et al. 2015, Forsyth et al. 2016, Sales et al. 2017, Pittiglio et al. 2018). Such studies were based on models using camera traps and indirectly on signs and presence/ absence data of wild pig associated with environmental (vegetation type and topography) and climatic variables, besides anthropogenic effects. These analyses revealed that areas occupied or with a potential to be occupied by wild pig are those where food and shelter are most abundant. Also, niche shifts in non-native areas might be explained mainly by the existence of unoccupied areas where the climate is similar to its native areas (Sales et al. 2017).

Native to Eurasia and north of Africa, the wild pig were introduced in South America at the beginning of the 20th century, invading Brazil by late 1980 s from Uruguay into the southern part of the State of Rio Grande do Sul (Deberdt \& Scherer 2007). In the wild, it interbred with the domestic pig (Sus scrofa domesticus Erxleben) resulting in fertile hybrids (Grossi et al. 2006), called "wild pig" (Keiter et al. 2016, Melletti \& Meijaard 2017). Wild pig are one of the several invasive species present in the Brazilian Atlantic Forest (Deberdt \& Scherer 2007, Hegel \& Marini 2013, Pedrosa et al. 2015). These native forests offer resources such as water, food, and humid areas, and have nowadays low density of large predators, like jaguars or pumas (Machado et al. 2008), which have the potential to prey upon large ungulates (Hegel \& Marini 2018). Wild pig impact on the Atlantic Forest is poorly known, but at a forest fragment in south Brazil, the impact on the native vegetation inside a reserve was evaluated and showed intense herbivory, rooting and soil overturning (Hegel \& Marini 2013). Also worryingly, wild pig consumes and destroy the seeds and cones (Deberdt \& Scherer 2007, Hegel \& Marini 2013) of the critically endangered Parana Pine (Araucaria angustifolia) (Thomas 2013), which has already lost 97\% of its geographical distribution (Gantzel 1982, Guerra et al. 2002). The increasing abundance and economic damage, such as partial loss of crop plantations, caused by wild pig in Brazil have promoted a series of laws by Brazilian governmental agencies allowing wild pig hunting (see IBAMA $n^{\circ} 03$ of 31 January 2013, reissued in IBAMA $n^{\circ} 12$ of 25 March 2019). However, there are no current estimates of wild pig densities and expansion rates at the Atlantic Forest. Finally, it is worthy to mention that the Atlantic Forest has lost approximately $90 \%$ of its original distribution (Ribeiro et al. 2009), is a world hotspot (Myers et al. 2010), and is still being deforested in the last decades (SOS Mata Atlântica 2014).

Thus, considering the potential threat of wild pig to native species and habitats, the high endangerment of the Atlantic Forest, and the scarcity of studies about the recent invasion of wild pig in the region, we tested the hypothesis that wild pig occupation patterns in the Atlantic Forest are related to vegetation types and landscape variables, resembling the patterns found in other native and non-native areas. To accomplish that, we estimated wild pig detection $(p)$ and occupancy $(\psi)$ probabilities in the Atlantic Forest. The findings provide unique information about how wild pig occupy an altered Atlantic Forest landscape, with potential applications to conservation and management plans.

\section{Material and Methods}

\section{Study site}

We conducted this study at the 'Campos de Cima da Serra' region, southern Brazil (28 13 '54.2" S and 51 ${ }^{\circ} 10^{\prime} 14.9^{\prime}$ ' W), at the southern part of the Atlantic Forest. We studied a region up to $50 \mathrm{~km}$ centered at the reserve 'Estação Ecológica de Aracuri-Esmeralda' (EEAE, with 275 ha), municipality of Muitos Capões, Rio Grande do Sul (Figure 1, Supplementary Table S1). Today, the vegetation of the region is composed of patches of disturbed Mixed Ombrophilous Forest, a type of Atlantic forest of southern Brazil with Araucaria angustifolia as the most emblematic tree, in a matrix of native grasslands, wetlands, secondary vegetation, 'vassorais' (Baccharis dominated vegetation) and crop plantations (Brasil 2008). The study region is located around 700-950 m elevation with mean annual rainfall ranging from 1,700 to 2,200 $\mathrm{mm}$ well distributed along the year and mean annual temperature ranging from $14^{\circ}$ and $16^{\circ} \mathrm{C}$ (Brasil 2008), with four well defined seasons.

\section{Sampling sites and variables}

We conducted a 10-day sampling design preliminary study at the end of July 2015, using one camera-trap in each of 16 sites. Then, we used this result to simulate in program MARK (White \& Burnham 1999) the number of days and sampling units necessary to estimate our parameters of interest (i.e., occupancy $(\psi)$ and detection $(p)$ probabilities) during one single season. Based on the results of this simulation we designed our study to register wild pig with camera traps during 8 days at 100 

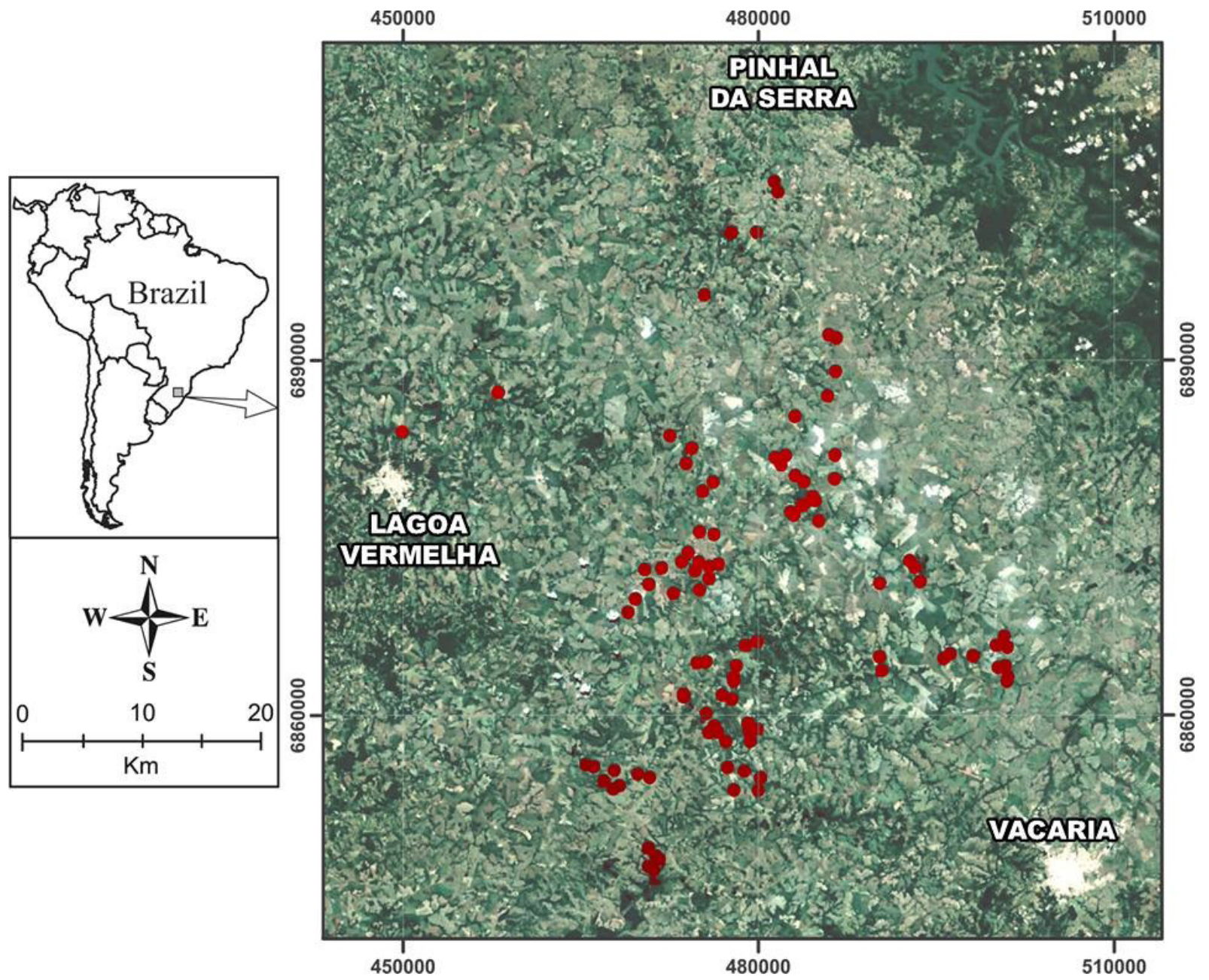

Figure 1. Wild pig (Sus scrofa) occupancy study region showing the sampling sites (red dots) in the Atlantic Forest, state of Rio Grande do Sul, southern Brazil.

sampling sites distributed up to $50 \mathrm{~km}$ around EEAE, at least $1 \mathrm{~km}$ apart from each other (a distance also used by Gantchoff \& Belant 2015 and Forsyth et al. 2016) (Figure 1). To improve detectability, all 100 sampling sites were selected based on previous vestiges of the presence of wild pig at each site, such as hair, feces, footprints, overturned soil, trunk damage, and sightings. We set up 16 cameras during six consecutive 8-day periods, and four cameras during the 8-day period from September 8 to November 3, 2015 (adding to 800 camera/days). This period of sampling was used for logistical reasons spanning the end of winter and the beginning of spring.

At each site, the percentage of four vegetation types (native forests, native grasslands, wetlands, and crop plantations) was estimated around $500 \mathrm{~m}$ from the point that each camera was mounted using Google Earth images treated with ArcGIS (Esri 2011). Overall, the native forest was the most common vegetation type $(56.5 \%$ of the area), followed by crop plantations $(25.7 \%)$, native grasslands $(9.9 \%)$, and wetlands $(7.8 \%)$. To run the single-season occupancy modeling analysis, we used six variables: two landscape variables (distance from roads - categorical, up to $50 \mathrm{~m}$ and further than $50 \mathrm{~m}$, and distance from running watercourses - categorical, up to $30 \mathrm{~m}$ and further than $30 \mathrm{~m}$ ) and the four vegetation types, each one as a variable (native forests, native grasslands, wetlands, and crop plantations (encompassing oat, corn, soybean, wheat, apple and grape orchards). We excluded Pinus sp. plantations from the analyses since they represented only a very small portion $(0.12 \%)$ of total vegetation.

\section{Statistical analyses}

We used a single-season occupancy modeling approach to estimate occupancy $(\psi)$ and detection $(p)$ probabilities of wild pig (Mackenzie et al. 2002). The assumptions of the method are that (1) within the sampling period the occupancy status of the species was closed (no colonization or extinction occur during the sampling) (Mackenzie et al. 2006); (2) the probability of detecting the species was independent among sampled sites; and (3) the species was not falsely detected. We considered occupancy as a measure of habitat use, because home ranges of wild pig may exceed the size of our sampling unit $(0.7-6$ $\mathrm{km}^{2}$ ) (Baber \& Coblentz 1986, Ilse \& Hellgren 1995, Gabor et al. 1999). The assumption that sites are close to changes in occupancy during the sampling occasions may be relaxed if changes in the occupancy status of sites are random. In this case, occupancy should be interpreted as 'use' and movement throughout the sampled sites (Mackenzie et al. 2004; Mackenzie \& Royle 2005). The detection probability incorporated to the models accounts for imperfect detection, reducing bias in parameters estimation (Mackenzie et al. 2006). 
Our modeling process followed three steps in program MARK (White \& Burnham 1999). First, we built a global additive model with occupancy varying by the presence of running watercourses (water), roads (road), amount of forest (forest), grassland (grass), wetlands (wetlands), and crop plantations (crops). In this global model, we maintained detection constant because the temporal version did not estimate all parameters, and because we did not have specific hypotheses on detection variation. Next, we built a set of 64 models with all possible combinations. This resulted in a balanced model set to estimate the importance (cumulative weights, hereafter $w_{i}^{+}$) of each landscape variable, following the recommendation of Burnham \& Anderson (2002). Finally, to have a reliable set of candidate models, we excluded from the analysis models with non-informative parameters, following Arnold (2010). Although vegetation variables appeared as non-informative parameters, we decided to maintain models with these variables based on our field observations and the importance of vegetation to the presence and distribution of wild pig. We conducted goodness-of-fit analysis with program PRESENCE (Hines 2006) to evaluate the global model fit and to estimate the variance inflation factor (c-hat), which we used to adjust the Akaike's Information Criterion for small sample size (QAIC ${ }_{c}$, see Mackenzie \& Bailey 2004). We used QAIC $_{c}$ to rank competing models and we considered models with $\triangle$ QAIC $_{\mathrm{c}}$ values $<2$ equally supported and used them to make inferences (Burnham \& Anderson 2002). We considered the QAIC ${ }_{\mathrm{c}} w_{i}$ (hereafter $w_{i}$ ) as the relative weight of support of each model and we model-averaged occupancy $\left(\psi_{i}\right)$ across the final set of models (Burnham \& Anderson 2002, Doherty et al. 2012). Finally, we did not use null $p$-values to clarify uncertainties in the modeling to avoid mixing the paradigms "hierarchical model selection" and "null hypothesis testing", following Wasserstein et al. (2019).

\section{Results}

We recorded wild pig in 64 of the 100 sampled sites in the Atlantic Forest. We built all possible combinations of additive models, resulting in a set of 64 models (Supplementary Table S2). In these models, the variable "water" had the highest cumulative weight $\left(w_{i}^{+}=0.60\right)$, followed by "crops" $\left(w_{i}^{+}=0.34\right)$, "grass" $\left(w_{i}^{+}=0.31\right)$, "forest" $\left(w_{i}^{+}\right.$ $=0.29)$, "wetlands" $\left(w_{i}^{+}=0.27\right)$, and "roads" $\left(w_{i}^{+}=0.25\right)$. After excluding from the analysis models with non-informative parameters, only 11 models remained with the most important variables affecting detection and occupancy probabilities of wild pig. From these, the four top-ranked models accounted for $72.7 \%$ of the total model weight and $\triangle$ QAICc $<2$ (Table 1). We considered them to explain variation in occupancy probability of wild pig in the Atlantic Forest. The top model $\left(\mathrm{w}_{\mathrm{i}}=0.285\right)$ had "water" as a covariate on occupancy, in the second model the occupancy was "constant" $\left(\mathrm{w}_{\mathrm{i}}=0.208\right)$, and in the third and fourth models, the occupancy was explained by "crops" and "grass" ( $\mathrm{w}_{\mathrm{i}}$ of 0.123 and 0.111 ), respectively (Table 1 ).

No single variable highly explained wild pig occupancy in the Atlantic Forest (Tables 1 and 2). The two best models answered for $49.3 \%$ of the weight of all models ("water" $-28.5 \%$ and "constant" $20.8 \%$ ). However, the top model showed a slight tendency towards a negative effect of "water" (running watercourses), with a decrease of wild pig occupation at sampling sites close to running watercourses $(\beta$ $=-1.12 ; \mathrm{SE}=0.58)$. When the "water" variable was analyzed alone, the results indicated that in the presence of running watercourses the percentage of occupation by wild pig was lower (59\%) than in the absence of running watercourses $(82 \%)$. The second model, "constant", reinforces the generalist habit of wild pig indicating a random pattern of occupation of the landscape. The next models with the variables "crops", "grass", "forest", and "wetlands" had inconclusive tendencies with weak explanatory weights (between 7.2 and 12.3\%) (Table 1) and confidence intervals of the $\beta$ parameters overlapping zero (Table 2). Furthermore, "roads" did not contribute to explaining the occupation of wild pig ( $\beta$ $<0.001$; $\mathrm{SE}=0.51)$. Wild pig were detected equaly in areas with $(\mathrm{N}=$ $32)$ and without $(\mathrm{N}=32)$ roads near the sampling sites with cameras.

\section{Discussion}

Our results showed uncertainties about the influencing variables of wild pig occupation on South Atlantic Forest, indicating a random pattern of occupation of the landscape that reinforces the generalist habit of the species (Mayer \& Brisbin 2009; West et al. 2009). Nevertheless, we detected a slight tendency for a negative effect of running watercourses and wetlands on wild pig occupation. This is opposite to expected since McClure et al. (2015), in a macro-spatial study in the USA, found that both distance to water and landscape heterogeneity were important in their models, with localities far away from the water having lower occurrence of wild pig. This lower occupancy near running watercourses could represent a threat to young pig because of a higher danger of drowning when crossing deeper watercourses, because of hypothermia due to the low-fat content in the first months of live (Rosell et al. 2001). Also, wild pig tends to avoid areas near watercourses probably because of lower protection from predators (Kurz \& Marchinton 1972; Massei et al. 1997), which can prey upon juveniles and piglets (Hegel \& Marini 2018). However, wetlands are known to be used as a shelter, for breeding, feeding and mainly regulation of body temperature by mud baths (Mendina Filho et al. 2015), which can also help clean out ectoparasites (West et al. 2009). Other studies have shown that the only environmental condition that can effectively avoid the presence of wild pig in an area is the lack of superficial water (Mayer \& Brisbin 2009; Beasley et al. 2014). Also, wild pig prefer to construct nests in areas with dense cover and water nearby (Fernández-Llario 2004). One explanation for this contradiction between our results and previous studies is probably related to the $45 \%$ above average rainfall at our study site in 2015 (INPE 2016), related to an "El Niño" effect in the southern Neotropical region. Thus, the excess of rain, and of humid areas, might have changed landscape use by wild pig during our sampling, allowing them to occur in areas independently of local water availability.

The single-season occupancy modeling analysis indicated that there is no specific preference for any vegetation type by wild pig. Thus, the occupation patterns of wild pig showed that it is a habitat-generalist at the Atlantic Forest, similar to other native and introduced regions of the world, being found at several vegetation types, such as native and planted forests, grasslands, humid areas, and plantations (Spitz 1986 apud Oliver \& Leus 2008; Mayer et al. 2000; Wilson 2004). Accordingly, we also observed vestiges of wild pig in different vegetation types such as Pinus sp. plantations, and corn and oat crops. Similarly, in the USA, wild pig preferred Pinus sp. trees (Graves 1984), indicating that this species might be beneficial for wild pig at introduced localities. Wild 
Wild pig occupancy in the Atlantic forest

Table 1. Single-season occupancy modeling: 11 models generated to explain detection and occupancy of wild pig in the south Atlantic Forest, were $p=$ detection probability, and $\psi=$ occupancy probability. The table presents the values of QAICc, $\Delta$ QAICc, AICc weights $\left(w_{i}\right)$ of each model and the number of parameters (K).

\begin{tabular}{|c|c|c|c|c|}
\hline Model & QAICc & $\triangle Q \mathbf{Q A C C}$ & Weights $\left(w_{i}\right)$ & $\mathbf{K}$ \\
\hline$\Psi($ water $) \mathrm{p}()$. & 470.802 & 0 & 0.285 & 3 \\
\hline$\Psi(.) \mathrm{p}()$. & 471.431 & 0.629 & 0.208 & 2 \\
\hline$\Psi($ grass $) \mathrm{p}()$. & 472.683 & 1.880 & 0.111 & 3 \\
\hline$\Psi($ forest $) \mathrm{p}()$. & 473.055 & 2.252 & 0.092 & 3 \\
\hline$\Psi($ road $) \mathrm{p}()$. & 473.558 & 2.755 & 0.072 & 3 \\
\hline$\Psi($ water + wetlands + grass + forest + crops $) \mathrm{p}()$. & 477.495 & 6.692 & 0.010 & 7 \\
\hline$\Psi($ wetlands + grass + forest + crops $) \mathrm{p}()$. & 478.567 & 7.765 & 0.005 & 6 \\
\hline Global $\Psi($ road + water + wetlands + grass + forest + crops $) p()$. & 479.844 & 9.041 & 0.003 & 8 \\
\hline$\Psi($ road + wetlands + grass + forest + crops $) p()$. & 480.881 & 10.078 & 0.001 & 7 \\
\hline
\end{tabular}

Table 2. Single-season occupancy modeling: seven first models with one variable to explain beta values each parameter, were $\beta=$ value of the variable beta parameter, $\mathrm{SE}=$ standard error, $\mathrm{CI}=$ lower and upper limits of $95 \%$ Confidence Interval.

\begin{tabular}{lcccc}
\hline Model & $\boldsymbol{\beta}$ & SE & CI & \\
\hline$\Psi($ water) $\mathrm{p}()$. & -1.1219 & 0.5895 & -2.2773 & 0.0335 \\
$\Psi$ (crops) $\mathrm{p}()$. & -2.6349 & 2.1169 & -6.7840 & 1.5142 \\
$\Psi$ (grass) $\mathrm{p}()$. & 2.6147 & 2.3915 & -2.0727 & 7.3021 \\
$\Psi$ (forest) $\mathrm{p}()$. & 3.8165 & 4.8289 & -5.6482 & 13.2812 \\
$\Psi$ (wetlands) $\mathrm{p}()$. & -3.5177 & 4.6996 & -12.7290 & 5.6935 \\
$\Psi$ (roads) $\mathrm{p}()$. & $0.26 \mathrm{E}-5$ & 0.5166 & -1.0125 & 1.0125 \\
\hline
\end{tabular}

pig are attracted to areas with these trees, at least in part because of their behavior of rubbing their bodies against trees to remove parasites after mud baths (Campbell \& Long 2009). The preference of wild pig for conifers might also be related to antimicrobial activity against bacteria and fungi, properties of the resin that helps heal wounds (Sipponen et al. 2012). A native conifer, the Parana pine Araucaria angustifolia, which occurs at southern Atlantic forests, is also used by wild pig for rubbing (C. Hegel, pers. obs.), and as a food source (Deberdt \& Scherer 2007, Hegel \& Marini 2013). Wild pig presented a seasonal variation in occupation in coniferous forests of New Zealand, being present in more places in the summer than in the winter (Forsyth et al. 2016).

In turn, because of wild pig broad diet, food available in the forests is not expected to be a limiting factor (Ballari \& Barrios-García 2014). We observed vestiges of the presence of the wild pig especially in corn and oat plantations, but not in other cultures and plantations (soybean, wheat, and apple and grape orchards), though they were poorly sampled. Thus, proper year-round use of habitats is necessary to evaluate seasonal and spatial use of the landscape. Wild pig are known to consume large amounts of several crops (oat, corn, sugar cane, wheat, sorghum, barley, and oilseeds) as well as tree saplings in the USA (Mayer et al. 2000). In Spain, wild pig often occurred in large forest fragments surrounded by crops, and adjacent to other large forests close to mountains or riparian forests (Virgós 2002). Also, Caley (1993) found that wild pig consumes not only standing crops but also rooting crop residues after harvest, evidencing its food flexibility. Since wild pig have a generalist diet, the potential impact on specific crops should be evaluated throughout the year and at different stages of each crop.
Areas of grasslands also had no effect on the detection or occupancy of wild pig at out study site. Native grasslands at our study site might have been used, like roads, only for movement among adjacent vegetation types. However, wild pig caused vegetation disturbance in pasturelands and plantations adjacent to forests in southern England (Wilson 2004). Roads were used by wild pig to move among preferred habitats, such as humid areas and crops (Mayer \& Brisbin 2009; Beasley et al. 2014). In Argentinian Patagonia, wild pig were present only in humid lands, and occupancy was lower closer to settlements but higher closer to roads (Gantchoff \& Belant 2015).

Although our study has seasonal limitations of sampling and the possible influence of a climatic phenomenon that increases the precipitation in the south of Brazil, our results are similar to other regions either where wild pig are native or introduced. Here, wild pig showed an overall broad and unselective use of the landscape occupying most vegetation types, with a poor relationship with running waterbodies and roads. The tendency of higher occupation of some vegetation types demonstrates only weak preferences, such as for forests, and some crops, such as corn and oat. This broad occupation pattern stresses the major potential of invasion of wild pig even at subtropical regions like the southern Atlantic Forest. The rich and highly fragmented and altered Atlantic Forest, a world hotspot, seems prone to be invaded by wild pig since wild pig can benefit from and occupy the current mosaic of vegetation types in the region. The fact that wild pig can cause economic and environmental impacts is worrisome, requiring urgent attention by governmental authorities to manage and control wild pig, especially in pine forests and other forest types in the Atlantic Forest domain, 
before their populations increase even further. We also recommend the financial incentive to year-round studies of wild pig occupation patterns not only in the Atlantic Forest but also in other Brazilian environments and their transition areas.

\section{Supplementary material}

The following online material is available for this article:

Table S1 - Geographical coordinates and name of the localities of the 100 sampling sites.

Table S2 - Single-season occupancy modeling: 64 models generated to explain detection and occupancy of wild pig in the south Atlantic Forest.

\section{Acknowledgements}

CAPES provided a Master fellowship to CGZH. We thank URI and UnB for support and ICMBio for the license to conduct research at ESEC Aracuri-Esmeralda. We also thank the land owners, employees and feral pig controllers for access to their properties and field assistance. J. R. S. Vitule, L. U. Hepp, R. Fornel and J. A. B. Monsalvo provided criticisms on previous drafts of the manuscript. MÂM held a researcher fellowship from CNPq.

\section{Author Contributions}

Carla Grasiele Zanin Hegel - Substantial contribution in the concept and design of the study; Contribution to data collection; Contribution to data analysis and interpretation; Contribution to manuscript preparation.

Luane Reis dos Santos - Substantial contribution in the concept and design of the study; Contribution to data analysis and interpretation; Contribution to manuscript preparation.

Mauro Pichorim - Contribution to data analysis and interpretation; Contribution to manuscript preparation, Contribution to critical revision, adding intellectual content.

Miguel Ângelo Marini - Substantial contribution in the concept and design of the study; Contribution to data analysis and interpretation, Contribution to manuscript preparation; Contribution to critical revision, adding intellectual content.

\section{Conflicts of interest}

The authors declare that they have no conflict of interest related to the publication of this manuscript.

\section{References}

ACEVEDO, P., ESCUDERO, M.A., MUŃOZ, R. \& GORTÁZAR, C. 2006. Factors affecting wild boar abundance across an environmental gradient in Spain. Acta Theriol. 51:327-336.

ACEVEDO, P., QUIROÂS-FERNÂNDEZ, F., CASAL, J. \& VICENTE, J. 2014. Spatial distribution of wild boar population abundance: Basic information for spatial epidemiology and wildlife management. Ecol. Indicators 36:594-600.
ARNOLD, T.W. 2010. Uninformative parameters and model selection using Akaike's Information Criterion. J. Wildl. Manag. 74(6):1175-1178.

BABER, D.W. \& COBLENTZ, B.E. 1986. Density, home range, habitat use, and reproduction in feral pigs on Santa Catalina Island. J. Mammal. 67:512-525.

BALLARI, S.A. \& BARRIOS-GARCÍA, M.N. 2014. A review of wild boar Sus scrofa diet and factors affecting food selection in native and introduced ranges. Mammal Rev. 44(2):124-134.

BARRIOS-GARCÍA, M.N. \& BALLARI, S.A. 2012. Impact of wild boar (Sus scrofa) in its introduced and native range: a review. Biol. Invasions 14:2283-2300.

BASKIN, L.M. \& DANELL, K. 2003. Ecology of ungulates: A handbook of species in Eastern Europe and Northern and Central Asia. Berlin: Springer.

BEASLEY, J.C., GRAZIA, T.E., JOHNS, P.E. \& MAYER, J.J. 2014. Habitats associated with vehicle collisions with wild pigs. Wildl. Res. 40(8):654-660.

BLACKBURN, T.M., PYŠEK, P., BACHER, S., CARLTON, J.T., DUNCAN, R.P., JAROŠÍK, V., WILSON, J.R.U. \& RICHARDSON, D.M. 2011. A proposed unified framework for biological invasions. Trends Ecol. Evol. 26(7):333-339.

BOSCH, J., PERIS, S., FONSECA, C., MARTINEZ, M., DE LA TORRE, A., IGLESIAS, I. \& MUÑOZ, M.J. 2012. Distribution, abundance and density of the wild boar on the Iberian Peninsula, based on the CORINE program and hunting statistics. Fol. Zoolig. 61:138-151.

BOSCH, J., MARDONES, F., PEÂREZ, A., DE LA TORRE, A. \& MUÑOZ, M.J. 2014. A maximum entropy model for predicting wild boar distribution in Spain. Spanish J. Agricult. Res. 12(4):984-999.

BRASIL. 2008. Plano de Manejo da Estação Ecológica Aracuri-Esmeralda. Instituto Chico Mendes de Conservação da Biodiversidade, Brasília.

BURNHAM, K.P. \& ANDERSON, D.R. 2002. Model selection and multimodel inference: a practical information-theoretic approach. Ecological Modelling. Springer Science \& Business Media, New York, New York, USA.

CALEY, P. 1993. Population dynamics of feral pigs (Sus scrofa) in a tropical woodland habitat complex. Wildl. Res. 20:625-636.

CAMPBELL, T.A. \& LONG, D.B. 2009. Feral swine damage and damage management in forested ecosystems. For. Ecol. Manag. 257:2319-2326.

CHAPIN III, F.S., ZAVALETA, E.S., VALERIE, E.T., NAYLOR, R.L., VITOUSEK, P.M., REYNOLDS, H.L., HOOPER, D.U., LAVOREL, S., SALA, O.E., HOBBIE, S.E., MACK, M.C. \& DÍAZ, S. 2000. Consequences of changing biodiversity. Nature 405:234-242.

DEBERDT, A.J. \& SCHERER, S.B. 2007. O javali asselvajado: ocorrência e manejo da espécie no Brasil. Nat. \& Conserv. 5:31-44.

DOHERTY, P., WHITE, G. \& BURNHAM, K. 2012. Comparison of model building and selection strategies. J. Ornithol. 152:317-323.

ESRI. 2011. ArcGIS Desktop: Release 10. Redlands, CA: Environmental Systems Research Institute.

FERNÁNDEZ-LLARIO, P. 2004. Environmental correlates of nest site selection by wild boar Sus scrofa. Acta Theriol. 49:383-392.

FORSYTH, D.M., ALLEN, R.B., ALLEN, R.K., AFFELD, K. \& MACKENZIE, D.I. 2016. Soil phosphorus predicts feral pig (Sus scrofa) occupancy, detection probability and feeding activity in a temperate montane rainforest. Wildl. Res. 43(4):277-287.

GABOR, T.M., HELLGREN, E.C., VAN DEN BUSSCHE, R.A. \& SILVY, N.J. 1999. Demography, sociospatial behavior and genetics of feral pigs (Sus scrofa) in a semi-arid environment. J. Zool. 247:311-322.

GANTCHOFF, M.G. \& BELANT, J.L. 2015. Anthropogenic and environmental effects on invasive mammal distribution in northern Patagonia, Argentina. Mammal. Biol. Zeitschr. Säuget. 80(1):54-58.

GANTZEL, O.L. 1982. Avaliação das florestas de Araucaria angustifolia (Bert.) O. Ktze. do sul do Brasil, através de imagens do satélite LANDSAT-II. Rev. Floresta 28:38-40. 
GRAVES, H.B. 1984. Behavior and ecology of wild and feral swine (Sus scrofa). J. Animal Sci. 58(2):482-492.

GROSSI, S.F., LUI, J.F., GARCIA, J.E. \& MEIRELLES, F.V. 2006. Genetic diversity in wild (Sus scrofa scrofa) and domestic (Sus scrofa domestica) pigs and their hybrids based on polymorphism of a fragment of Dloop region in the mitochondrial DNA. Genet. Mol. Res. 5(4): 564-568.

GUERRA, M.P., SILVEIRA, V., REIS, M.S. \& SCHNEIDER, L. 2002. Exploração, manejo e conservação da araucária (Araucaria angustifolia). In: L.L. Simões; C.F. Lino (orgs.), Sustentável Mata Attântica: A Exploração de seus Recursos Florestais. São Paulo, Senac, 85-102.

GUREVITCH, J. \& PADILLA, D.K. 2004. Are invasive species a major cause of extinctions? Trends Ecol. Evol. 19(9):470-474.

HADJISTERKOTIS, E. 2004. The introduction of wild boar Sus scrofa L. on the Island of Cyprus. Galemys 16 (Special edition):233-242.

HEGEL, C.G.Z. \& MARINI, M.Â. 2013. Impact of the wild boar, Sus scrofa, on a fragment of Brazilian Atlantic Forest. Neotrop. Biol. Conserv. 8:17-24

HEGEL, C.G.Z. \& MARINI, M.Â. 2018. Large felids as predators of wild boar in the Atlantic Forest: reconciling Verdade et al. and Rosa et al. Anim. Conserv. 21:363-364.

HINES, J.E. 2006. PRESENCE 3.1 Software to estimate patch occupancy and related parameters. http://www.mbr-pwrc.usgs.gov/software/presence.html.

HONDA, T. 2009. Environmental factors affecting the distribution of the Wild Boar, Sika Deer, Asiatic Black Bear and Japanese Macaque in Central Japan, with implications for human-wildlife conflict. Mammal Study 34(2):107-116

IBAMA. 2013. Instrução Normativa Ibama $\mathrm{N}^{\circ} 03$ de 31 de janeiro de 2013 do Instituto Brasileiro do Meio Ambiente e dos Recursos Renováveis (IBAMA). Brasília: Ministério do Meio Ambiente (MMA).

IBAMA. 2019. Instrução Normativa Ibama No 12 de 25 de março de 2019 do Instituto Brasileiro do Meio Ambiente e dos Recursos Renováveis (IBAMA). Brasília: Ministério do Meio Ambiente (MMA).

ILSE, L.M. \& HELLGREN, E.C. 1995. Spatial use and group dynamics of sympatric collared peccaries and feral hogs in southern Texas. J. Mammal. 76:993-1002.

INPE - Instituto Nacional de Pesquisas Espaciais. 2016. Available at: www.inpe. br/. Accessed 06 April 2017.

IUCN - International Union for Conservation of Nature. 2019. The IUCN red list of threatened species. Available at: http://www.iucnredlist.org/search/ details. Accessed 10 May 2019.

JEDRZEJEWSKA, B., JEDRZEJEWSKI, W., BUNEVICH,A.N., MILKOWSKI, L. \& KRASINSKI, A. 1997. Factors shaping population densities and increased rates of ungulates in Bialowieza Primeval Forest (Poland and Belarus) in the 19th and 20th centuries. Acta Theriol. 42:399-451.

KEITER, D.A., MAYER, J.J. \& BEASLEY, J.C. 2016. What is in a "common" name? A call for consistent terminology for nonnative Sus scrofa. Wildl. Soc.Bull. 40(2): 384-387.

KURZ, J.C. \& MARCHINTON, R.L. 1972. Radiotelemetry studies of feral hogs in South Carolina. J. Wildl. Manag. 36:1240-1248.

LEAPER, R., MASSEI, G., GORMAN, M.L. \& ASPINALL, R. 1999. The feasibility of reintroducing Wild boar (Sus scrofa) to Scotland. Mammal Rev. 29:239-259.

LOWE, S., BROWNE, M., BOUDJELAS, S. \& DE POORTER, M. 2000. 100 of the world's worst invasive alien species: a selection from the global invasive species database (Vol.12). Auckland: Invasive Species Specialist Group.

MACHADO, A.B.M., DRUMMOND, G.M. \& PAGLIA, A.P. 2008. Livro vermelho da fauna brasileira ameaçada de extinção. In Livro vermelho da fauna brasileira ameaçada de extinção. MMA; Fundação Biodiversitas.

MACKENZIE, D.I., NICHOLS, J.D., LACHMAN, G.B., DROEGE, S., ROYLE, J.A. \& LANGTIMM, C.A. 2002. Estimating site occupancy rates when detection probabilities are less than one. Ecology 83:2248-2255.

MACKENZIE, D.I., BAILEY, L.L. \& NICHOLS, J. 2004. Investigating species co-occurrence patterns when species are detected imperfectly. J. Anim. Ecol. 73: 546-555.
MACKENZIE, D.I., NICHOLS, J.D., ROYLE, J.A., POLLOCK, K.H., BAILEY, L.L. \& HINES, J.E. 2006. Occupancy estimation and modeling: inferring patterns and dynamics of species occurrence. Academic Press, Burlington.

MACKENZIE, D.I. \& BAILEY, L.L. 2004. Assessing the fit of site-occupancy models. J. Agr. Biol. Envir. St. 9(3):300-318.

MACKENZIE, D.I. \& ROYLE, J.A. 2005. Designing occupancy studies: general advice and allocating survey effort. J. Appl. Ecol. 42:1105-1114.

MARTIN, M.R., TIPPING, P.W. \& SICKMAN, J.O. 2009. Invasion by an exotic tree alters above and belowground ecosystem components. Biol. Invasions 11:1883-1894.

MASSEI, G. \& GENOV, P.V. 2004. The environmental impact of wild boar. Galemys 16 (Special edition):135-145.

MASSEI, G., GENOV, P.V., STAINES, B. \& GORMAN, M.L. 1997 Factors influencing home range and activity of wild boar (Sus scrofa L.) in a Mediterranean coastal area. J. Zool. 242:411-423.

MAYER, J.J. \& BRISBIN, I.L.JR. (Eds). 2009. Wild pigs: Biology, damage, control techniques and management. SRNL-RP-2009- 00869. (Savannah River National Laboratory: Aiken, SC).

MAYER, J.J., NELSON, E.A. \& WIKE, L.D. 2000. Selective depredation of planted hardwood seedlings by wild pigs in a wetland restoration area. Ecol. Eng. 15:S79-S85.

MCCLURE, M.L., BURDETT, C.L., FARNSWORTH, M.L., LUTMAN, M.W., THEOBALD, D.M., RIGGS, P.D., GREAR, D.A. \& MILLER, R.S. 2015. Modeling and mapping the probability of occurrence of invasive wild pigs across the contiguous United States. PloS One 10(8):e0133771.

MELlETTI, M. \& MEIJAARD, E. 2017. Ecology, Conservation and Management of Wild Pigs and Peccaries. Cambridge University Press, Cambridge.

MENDINA FILHO, L.H., WALLAU, M.O. \& DOS REIS, T.X. 2015. O javali no Pampa: contexto, biologia e manejo. Pallotti, Santana do Livramento. 87p.

MYERS, N., MITTERMEIER, R.A., MITTERMEIER, C.G., FONSECA, G.A.B. \& JENNIFER, K. 2000. Biodiversity hotspots for conservation priorities. Nature 403:853-858.

MYRPHY, M.J., INMAN-NARAHARI, F., OSTERTAG, R. \& LITTON, C.M. 2014. Invasive feral pigs impact native tree ferns and woody seedlings in Hawaiian forest. Biol. Invasions 16:63-71.

OLIVER, W.L.R. \& BRISBIN, I.L. 1993. Introduced and feral pigs: Problems, policy and priorities. In: Oliver WLR (ed) Status Survey and Conservation Action Plan. Pigs, Peccaries and Hippos. IUCN, pp. 159-191.

OLIVER, W. \& LEUS, K. 2008. Sus scrofa. The IUCN Red List of Threatened Species 2008: e.T41775A10559847. http://dx.doi.org/10.2305/IUCN. UK.2008.RLTS.T41775A10559847.en. Accessed on 28 March 2018.

OSTFELD, R.S. \& KEESING, F. 2000. Pulsed resources and community dynamics of consumers in terrestrial ecosystems. Trends Ecol. Evol. 15:232-237.

PEDROSA, F., SALERNO, R., PADILHA, F.V.B. \& GALETTI, M. 2015. Current distribution of invasive feral pigs in Brazil: economic impacts and ecological uncertainty. Nat. \& Conserv. 13:84-87.

PITTIGLIO, C., KHOMENKO, S. \& BELTRAN-ALCRUDO, D. 2018. Wild boar mapping using population-density statistics: From polygons to high resolution raster maps. PloS One, 13(5):e0193295.

RIBEIRO, M.C., METZGER, J.P., MARTENSEN, A.C., PONZONI, F.J. \& HIROTA, M.M. 2009. The Brazilian Atlantic Forest: How much is left, and how is the remaining forest distributed? Implications for conservation. Biol. Conserv. 142:1141-1153.

ROSELL, C., FERNÁNDEZ-LLARIO, P. \& HERRERO, J. 2001. El jabalí (Sus scrofa Linnaeus, 1758). Galemys 13(2):1-25.

SALES, L.P., RIBEIRO, B.R., HAYWARD, M.W., PAGLIA, A., PASSAMANI, M. \& LOYOLA, R. 2017. Niche conservatism and the invasive potential of the wild boar. J. Animal Ecol. 86(5):1214-1223. 
Hegel, C.G.Z. et al.

SIMBERLOFF, D., MARTIN, J-L., GENOVESI, P., MARIS, V., WARDLE, D.A., ARONSON, J., COURCHAMP, F., GALIL, B., GARCÍA-BERTHOU, E., PASCAL, M., PYŠEK, P., SOUSA, R., TABACCHI, E. \& VILÀ, M. 2013. Impacts of biological invasions: What's what and the way forward. Trends Ecol. Evol. 28:58-66.

SIPPONEN, A., KUOKKANEN, O., TIIHONEN, R., KAUPPINEN, H. \& JOKINEN, J.J. 2012. Natural coniferous resin salve used to treat complicated surgical wounds: pilot clinical trial on healing and costs. Int. J. Dermatol. 51:726-732.

SOS Mata Atlântica. 2014. Relatório do Viva a Mata 2014.30p. Available at: https:// www.sosma.org.br/wp-content/uploads/2014/09/RelatorioVM_2014_SITE. pdf.

THOMAS, P. 2013. Araucaria angustifolia. The IUCN Red List of Threatened Species 2013: e.T32975A2829141. http://dx.doi.org/10.2305/IUCN. UK.2013-1.RLTS.T32975A2829141.en. Accessed on 27 May 2017.
VIRGÓS, E. 2002. Factors affecting wild boar (Sus scrofa) occurrence in highly fragmented Mediterranean landscapes. Can. J. Zool. 80:430-435.

VITULE, J.R.S., FREIRE, C.A., VAZQUEZ, D.P., NUÑEZ, M.A. \& SIMBERLOFF, D. 2012. Revisiting the potential conservation value of non-native species. Conserv. Biol. 26:1153-1155.

WASSERSTEIN, R.L., SCHIRM, A.L. \& LAZAR, N.A. 2019. Moving to a World Beyond " $\mathrm{p}<0.05$ ". Am. Stat. 73(sup1):1-19.

WEST, B.C., COOPER, A.L. \& ARMSTRONG, J.B. 2009. Managing wild pigs: A technical guide. Human-Wildl. Interact. Monogr. 1:1-55.

WHITE, G.C. \& BURNHAM, K.P. 1999. Program MARK: survival estimation from populations of marked animals. Bird Study 46 (Supplement):120-138.

WILSON, C.J. 2004. Rooting damage to farmland in Dorset, southern England, caused by feral wild boar Sus scrofa. Mammal Rev. 34:331-335. 